\title{
Analyzing vulnerable children and adolescents' health promotion in a civil-society organization in Florianopolis-SC
}

\author{
| ${ }^{1}$ Bruna Lima Selau, ${ }^{2}$ Douglas Francisco Kovaleski, Marina Bastos Paim |
}

Abstract: After the redemocratization, partnerships between the State and civil-society organizations have been guaranteed by the Constitution as a democratic tool. With the rise of neoliberalism and the decrease in State investments in social policies, such organizations have become protagonists in the health care, education, and protection of children in vulnerable situations. This study aims to analyze health promotion in the care for children and adolescents in a Civil-Society Organization (CSO) in Florianopolis-SC, Brazil. This is a case study with a qualitative approach in which semi-structured interviews were conducted, transcribed and analyzed using the thematic analysis method. The analysis resulted in two empirical categories: (1) Weaving networks between the State and Civil Society: intersectorality in health promotion; and (2) CSOs and the paths and deviations in pursuit of emancipatory health promotion. The analysis showed that, although CSOs include several health promotion initiatives for children and adolescents, intersectoral work still lacks effectiveness. Moreover, for emancipatory health promotion, it is necessary to work towards community empowerment and education for critical and social reflection.

> Keywords: children; adolescents; health promotion; intersectorality; civil-society organizations.

\author{
${ }^{1}$ Universidade Federal de Santa \\ Catarina. Florianópolis-SC, Brazil \\ (blselau@gmail.com). \\ ORCID: 0000-0003-4101-4444 \\ ${ }^{2}$ Universidade Federal de Santa \\ Catarina. Florianópolis-SC, Brazil \\ (douglas.kovaleski@ufsc.br). \\ ORCID: 0000-0001-8415-9614 \\ ${ }^{3}$ Universidade Federal de Santa \\ Catarina. Florianópolis-SC, Brazil \\ (marinabastosp@gmail.com). \\ ORCID: 0000-0003-3456-5598
}

Received: 09/16/2019 Approved: 05/22/2020 Revised: 07/09/2021 


\section{Introduction}

Throughout the history of care for poor and marginalized children and adolescents, care provision has often been "confused" with control and segregation, and what we found were actions of social exclusion, institutionalization, control, and stigma (RIZZINI; PILLOTE, 2011). Even with the creation of the Statute of the Child and Adolescent (ECA) and its social achievements in the 1990s, the production of care for children and adolescents is still a contemporary challenge. Therefore, it is necessary to reflect on how such care is currently provided.

Before ECA, in Brazil, civil society organizations (CSOs) operated through philanthropy and charity, with the Catholic Church being the main agent in providing such support (RIZZINI; PILLOTE, 2011). As a result of social struggles, the 1988 Constitution guaranteed rights to education, health, protection, leisure and culture to children and adolescents that had never been granted before. Legislation such as the Statute of the Child and Adolescent (ECA) was edited, and public policies were instituted to guide the care to be provided to that population. In order to guarantee the promotion and protection of children and adolescents' rights, instances of participation and social control were created to share the responsibility for children's care between the State and the civil society. Thus, the union of the State and society was made possible with a view to protecting and caring for children from a new perspective, involving new values of solidarity and social participation, rather than control, authoritarianism and social exclusion (VOGEL, 2011).

Even after the conquest of rights and the rise of social movements, many of the struggles could not get off the ground. It is undeniable that, with these legal achievements, there has been a lot of progress towards children and adolescents' rights. However, with the rise of neoliberalism in Brazil, even such achievements gradually began to be dismantled. Thus, starting in the 1980s, differently from the philanthropic and charity organizations that had previously operated, new civil-society organizations (CSOs) emerged which labeled themselves as "nongovernmental” (GOHN, 2000). This new strategy originated from global political changes and the work of activists in social movements on behalf of children and adolescents. Those organizations, known as non-governmental organizations (NGOs), have been gradually assuming a public - neither state nor private - non-profit role. This union of the State and the civil society has resulted 
in alternative projects, in confrontation with internment and repression strategies, thus acknowledging this population's rights.

Even considering the importance of CSOs in the consolidation of a democratic State and that their integration into the State was driven by the struggles of social movements in the redemocratization period, it is important to analyze the decrease in State investments in social policies and the accountability of the civil society as a protagonist in the solution of "social problems". With neoliberalism, the State and social policies are dismantled, and public services are undermined to the detriment of investments in companies (NAVARRO, 1991). Thus, there is not a reduction in the State, which starts investing in the market, but a reduction in investment in social issues.

In this context, CSOs have become protagonists in the daily health care, education and protection of vulnerable children. Their vulnerability is related not only to precarious income, but also to weak affective-relational bonds and unequal access to public goods and services (CARMO; GUIZARDI, 2018). Based on this scenario, it is necessary to reflect: how does this protagonism of CSOs affect the care for children and adolescents? How will this situation affect their care and health promotion? To answer these questions, it is essential to consider these children and adolescents' health care according to the principles and guidelines of the Unified Health System (SUS), which provide opportunities for health proposals that aim to produce autonomous individuals and a more equitable society.

From the sanitary reform on, there was a change in Brazil regarding the health care model, leading to a debate concerning the biomedical, hospital-centered, and curative model. Before, public health was based on scientific knowledge supported by bacteriology and microbiology. From this perspective, health was considered to be the absence of disease. However, changes in the demographic and epidemiological profile, along with globalization and the need to lower costs in health care systems, have brought new challenges to public health. Studies pointed to the need to incorporate socioeconomic, cultural and environmental aspects in the health-disease process in the face of changes in society and in the search for more effective solutions to the new profile of the population's illness (WESTPHAL, 2009). These discussions indicated the need for new health practices, among which was the incorporation of social determinants in the health-disease process as well as of strategies including intersectoral and interdisciplinary actions and social participation (PAIM, 2013). 
It is from this perspective that health promotion enters the SUS agenda as a health strategy. Health promotion includes strategies that promote the physical and mental well-being of individuals through the adoption of healthy lifestyles. But beyond this action, it understands health in its positive state, seeking biopsychosocial and spiritual well-being. Biological, psychological, socioeconomic, educational, cultural, political, and environmental conditions are considered determinants of health. Thus, health promotion bets on healthy and intersectoral public policies that account for the social determinants of health (WESTPHAL, 2009).

According to the 2015 National Health Promotion Policy (PNPS), its action should focus on individuals and communities, in a perspective of multidisciplinary, integrated and networked work, considering the population's health needs in an articulated manner with the various actors of a given territory (BRASIL, 2015). Thus, the health promotion strategy understands that an individual is not separated from his/her context and, thus, the action needs to encompass not only the individual, but also his/her reality. Moreover, health promotion must combat such naturalization of poverty and social inequality, so that the population's awareness results in social changes; it is a political commitment (PAIM, 2013).

With regard to health policies for children and adolescents, it is necessary to consider that there has been some progress after the redemocratization period, especially in health indicators, such as the reduction in infant mortality. On the other hand, there has been a change in the profile of health problems: external causes - accidents and violence - are currently the leading cause of death in the 1-19 age group. This new profile ultimately generates some less visible but more widespread problems, which are the effects of violence and children and adolescents' individual suffering (BRAZIL, 2010).

Even with guiding policies, specific legislation, and places owned both by the state and civil society organizations that act to protect children and adolescents, the care for this population segment remains a challenge. According to Barbiani (2016, p. 202):

[...] issues such as the death of thousands of children and adolescents from external causes, child labor, physical and sexual exploitation, school evasion, the threat of lowering the age of criminal responsibility, and the violation of rights in the execution of socio-educational measures are some examples of the magnitude of the challenges to be faced in order to ensure the full protection of children and adolescents. 
These new health challenges, especially in Latin America, are related to social inequalities that generate unfair and unnecessary differences in health. The essence of the problem concerning care provision to children and adolescents is intrinsic to the current economic system, and it is maintained by the dominant classes (RIZZINI; PILOTTI, 2011). Therefore, it becomes necessary to question the current health care practice in order to recover the guidelines of the Health Reform in pursuit of a more just and egalitarian society.

It is noteworthy that, although the State is aligned with the market and with the neoliberal ideal, it should not be unaccountable for the guarantee of rights that are established in the Constitution. It is essential to fight for investments in social areas and for public policies built in partnership with the civil society. Therefore, we emphasize that the participation of CSOs is indispensable, but the responsibility remains with the State. Moreover, the current situation points to the rise of conservative and neoliberal governments, and thus CSOs become an important element in guaranteeing citizenship rights, protecting the most vulnerable segments of society, and fighting for a more just and egalitarian society.

Considering the role of CSOs in the care for children and adolescents in vulnerable situations, together with the current political-economic scenario, it is necessary to understand how these institutions operate. Based on the concept of health built at the VIII National Health Conference, the concept of health promotion and networking strategies, this study aims to analyze health promotion in the care for children and adolescents in a CSO in Florianópolis-Santa Catarina.

\section{Methodological approach}

This study originated from the researcher's Master's thesis in Collective Health. The research was conducted with human beings, respecting and considering the ethical aspects, as provided for in Resolution No. 466/2012 by the National Health Council. The investigation was submitted to and approved by the Ethics Committee of the Federal University of Santa Catarina (UFSC), with project number 3037.236. ${ }^{\mathrm{i}}$

The case-study methodological approach was used, supported by comprehensive epistemology, considering that the unitary character of the studied object was preserved. From this approach in conjunction with qualitative research strategies, it is possible to "[...] map, describe and analyze the context, relationships and perceptions 
regarding the situation, phenomenon or episode in question" (MINAYO, 2010). The qualitative approach was chosen because it is believed to be able to incorporate social and subjective aspects necessary to understand individual and collective health processes (MINAYO, 2010).

The study was conducted in the municipality of Florianópolis, the capital city of Santa Catarina. The study field was a CSO located in the southern part of the municipality, which has a similar function to that of Centro de Convivência e Fortalecimento de Vinculos (Center for Co-living and Bonding Strengthening). In order to preserve the children's and the institution's identities, neither the location nor the institution's name will be disclosed.

$\mathrm{CSO}$ operates through a partnership with the municipal government of Florianópolis and serves children and adolescents in vulnerable situations that are referred by SUS. It is a non-profit entity founded on 11/28/1989, whose mission is to develop socio-educational activities with 80 children and adolescents, aged 6-15 years, in the after-school period. It provides educational activities and cultural projects, as well as physical, sporting and artistic practices. The income of the families assisted ranges from no income (unemployed) to two minimum wages. The study was conducted in two stages: a) the researcher's approach to CSO where the research and document analysis occurred; and b) the interviews.

The first stage consisted in recognizing the entity, which occurred firstly with the researcher's approach to its daily routine and document analysis. The following documents were analyzed: a) CSO's history; b) CSO's Pedagogical Policy Plan (PPP); c) National Health Promotion Policy (PNPS); d) SCFV's Guidelines Booklet; e) Technical Guidelines on the Co-living and Bonding Strengthening Service for Children and Adolescents aged 6-15 years. These materials were used to explore the theme and for further data analysis.

In the second moment, semi-structured interviews were conducted with five workers from the facility. The interviewees were: a) an administrative coordinator; b) a pedagogical coordinator; c) two educators; and d) a physical education teacher. The interviews took place in a reserved room according to the participants' availability. All the participants were previously introduced to the theme and signed an Informed Consent Form. The interviews were semi-structured, with 11 questions that were given depth. The interview lasted one hour on average. In order to preserve the participants' identity, fictitious names were used. 
The collected materials were transcribed and analyzed using thematic analysis. According to Minayo, thematic analysis "[...] consists in discovering the meaning units that constitute communication, whose presence or frequency means something to the analytical object pursued" (MINAYO, 2010, p. 316). The thematic analysis comprised three stages: pre-analysis, in which the exploration of the material and the treatment of results, inference and interpretation were performed, in addition to floating reading, corpus constitution and formulation and reformulation of hypotheses and objectives; exploration of the material, which consisted in the creation of initial categories that were later thematically grouped in order to reach the core of understanding of the text; and treatment of the results obtained and interpretation, which encompassed the analysis of the thematic groups that allowed placing the information obtained in evidence, as well as inferences and interpretations, according to the theoretical reference selected.

The analysis allowed grouping the answers into four categories: a) intersectorality; b) professional training; c) moral education, values, and citizenship; and d) assistentialism and social change. In this article the following categories will be discussed: (1) intersectorality and (2) assistentialism and social change, in order to further the debate and because they are interrelated categories.

\section{Results and Discussion}

In order to provide better understanding of the data analysis and of the material collected, the results were organized into two categories: (1) Weaving networks between the State and Civil Society: intersectorality in health promotion; and (2) CSOs and the paths and deviations in pursuit of emancipatory health promotion.

\section{Category I - Weaving networks between the State and Civil Society: intersectorality in health promotion}

With health? None. We don't see this. We see a little of the pedagogical, but a connection with health? (DANDARA)

This category aims to problematize intersectorality in the care for children and adolescents at CSOs and its influence on health promotion. The systematization of a CSO results from the union of different actors that go through the institution's daily routine and spaces, generating dilemmas and contradictions as a result of the 
lack of an expanded network, dialogue, and intersectoral work. These difficulties in implementing intersectorality eventually reflect directly on the care and health promotion for children and adolescents.

The CSO under analysis is funded by two departments that work directly in this space: social welfare and education. The Department of Education provides the teachers, pays for meals, and is responsible for teachers' continuing education through training meetings throughout the year. The Social Welfare Department subsidizes the pedagogical and administrative coordinators' salaries, helps with the purchase of materials, and is responsible for monitoring the service and attendance, as well as registering the children that are attended to. Thus, the neighborhood association that created the CSO is a State partner and responsible for providing the service to this community. Because the CSO is funded by the Departments of Education and Social Welfare, it must be accountable to the State and meet goals set by these different departments.

One of the difficulties found in this scenario of partnership between the State and the civil society was the lack of dialogue between these segments. The lack of information on how an intersectoral work operates - by both the departmentd and CSO employees - eventually creates insecurity instead of helping workers. This transfer of information in a hierarchical manner, without horizontal relations in the service construction, affects both the teachers and the daily lives of the children assisted.

[...] then the two departments have a "feud" [...] they don't work together, and this ends up having repercussions in the institution itself, because there is the Department of Education's discourse, and then there is the Social Welfare Department's discourse, and we end up beating our heads against it. (MARTA)

Despite these three players' participation with different views and knowledge, without a horizontal dialogue, intersectoral work does not occur. In this scenario, these three players do not meet to exchange information and create new service strategies. Intersectorality requires this type of interaction. According to Bellini et al. (2013, p. 2), intersectorality is:

[...] the integration of these various sectors for the achievement of public actions, while maintaining the specificities of each area. It extends beyond each sector, seeking to overcome fragmented practices and efficiency to achieve the objectives and results. Thus, intersectorality in public policies is understood as a greater articulation between different fields of knowledge to achieve a broader objective. 
From this perspective, intersectorality extends beyond the articulation among various sectors in the execution of public policies, and practices must not be fragmented. To this end, dialogue and joint planning of actions are fundamental for a horizontal articulation among the different agents involved and, above all, it must be focused on comprehensive users' care. Therefore, intersectorality is a management logic that articulates knowledge and experiences, aiming to overcome the fragmentation of social policies and build new responses to service provision and the relationship between such provision, the State, and citizens (BELLINI et al., 2013). Thus, what happens in CSOs cannot be considered intersectoral work, and this lack of intersectorality ultimately generates suffering for workers and compromises the service provided.

Another important characteristic is that the workers hired by the Department of Education have a licentiate degree, and in their statements, it was possible to perceive the difficulty encountered when the objective was to work with children and adolescents' health and protection. Even with weekly continuing education meetings for teachers, this course does not cover all the issues because the professionals often come in without any knowledge of how an SCFV works or of the social welfare and health care guiding policies, which makes it difficult to understand the work that will be performed.

[...] the teachers are here to work on the contents with them, because we are not here as babysitters, we are here as teachers, and then we get into this arm wrestling match, because Social Welfare says that this should be a more leisurely thing, more playful, they have to come here to play. But then, gee, if they have to come here to play, why does the Education Department keep providing teachers? (NÍSIA)

The teachers' resistance to work based on a different approach, to combine their knowledge with other ways of thinking and "create" a new way of performing their work is evident in their statements. Through dialogue, intersectorality, and the joint construction of education and social service, more effective forms of assistance could be developed. It is through a broadened view of the complexity of the demands and through horizontal dialogue that professional practice overcomes the fragmentation of the specific view of professional knowledge and places the user as the central point of care provision. According to Pombo $(2005$, p. 5), the difficulty in performing this action:

[...] has nothing to do with pluri, multi, trans, or interdisciplinarity. On the contrary, in the overwhelming majority of cases, it has to do with disciplinarity. It has everything to 
do with our inability to move beyond our own discursive principles, theoretical perspectives, and modes of operation in which we have been trained and educated.

Thus, it becomes very important to bring the interdisciplinarity discussion, and the concept of transdisciplinarity in particular, to integrate the care for children and adolescents. The term was coined by Piaget, and it is about overcoming the barriers existing between disciplines and connecting them through the communion of knowledge, thus creating a new idea that transcends them all; the search for the interaction of specialized praxis (MENDES; LEWGOY; SILVEIRA, 2008).

With the integration of transdisciplinarity, children and adolescents in vulnerable situations become the central focus of care, to the detriment of the dispute between different professions and fields of knowledge. Thus, working from the perspective of transdisciplinarity is "[...] to accept that we are actors of our intervention, but we are supporting actors; the protagonist is the subject to whom our practice is directed. Working in an interdisciplinary or transdisciplinary team is to harbor a democratic power" (MENDES; LEWGOY; SILVEIRA, 2008, p. 31).

The importance of networking was mentioned by the workers as indispensable for a real social transformation in that space. There are no meetings or continuous contact with CRAS, which is responsible for evaluating the cases and referring the children and adolescents who will be assisted by CSO. Likewise, there is no transfer of cases, nor a discussion of cases between the institutions. In addition, the institution does not participate in meetings of the child and adolescent protection network in Florianopolis or in CMDCA meetings. The lack of communication and information results in assistance failure and ultimately reduces the potential of the service and of health promotion for children and adolescents.

[...] they don't provide us with much detail, which is very complicated, because we are
the ones who take care of the children, not them. [...] the health care facility and CRAS,
at least this year, haven't shown up once, they don't know under what conditions we
assist the children, they send them here and then they don't even want to know how the
children are doing, if they are being well assisted, you know? [...] So these are very com-
plicated things. (NÍSIA)

This reality, portrayed at CSO, contradicts SCFV's general guidelines booklet, since the Technical Guidelines on the Co-living and Bonding Strengthening Service for children and adolescents aged 6 to 15 years (2010) state that these services should keep a relationship with professionals from other services, aiming to overcome 
the situation of vulnerability in which children or adolescents find themselves. In addition, quarterly intersectoral meetings are suggested to organize the territory's services and demands (BRASIL, 2010). Additionally, the CSO's official documents both PPP and the historical document - incorporate intersectorality as fundamental in the care for children and adolescents.

Thinking of networking with SUS, no health services articulation was found. It was reported that the health unit does not perform any activities on site and, in addition, cases of suspected illness are not referred to the health unit.

Yes, as regards health care, we have little connection, you know? With health services. With health units, there is virtually no link at all. In the old days, we still went there, sometimes, we could at least ask for an appointment for a child, but, nowadays, this doesn't exist anymore. (MARIA QUITÉRIA)

[...] because, then, we refer the family, so that the family can seek help if they need it, you know? [...] But we don't get any feedback from the family, so we don't know... (NÍSIA)

The lack of knowledge regarding health care processes within the child and adolescent protection network itself may eventually cause failures in the health care provision to these users. Therefore, it is necessary to integrate knowledge of both the health-disease process and the health care network, so that workers recognize which demands should be notified and referred to the health unit. This knowledge can and should be acquired through an integrated and interdisciplinary network.

According to Junqueira $(2004$, p. 26), “[...] the complexity of social problems requires several views, several ways to approach them, bringing together knowledge and practices for the understanding and integrated construction of solutions that can ensure a quality life for the population". Thus, intersectorality also enters the health care agenda through the expanded concept of health and health promotion. The guidelines of the National Health Promotion Policy (2010) ensure the promotion of intersectoral actions, seeking partnerships that enable the comprehensive development of health promotion actions.

Thus, these concepts become essential in the care provision agenda for children and adolescents, and the lack of intersectoral work and transdisciplinarity puts aside children and adolescents as the focus of care, and the complexities of the demands cannot be resolved. For Corrêa (2018), who conducted a study on intersectorality in the child and adolescent protection network, "[...] the complex demands from users require working from the perspective of intersectorality in order to create coping 
strategies for certain phenomena" (CORRÊA, 2018, p. 98). Therefore, these spaces should provide networked and comprehensive care between the State and the civil society, seeking to promote health.

\section{Category II - CSOs and the paths and deviations in pursuit of emancipatory health promotion}

The ideal thing would be working with the children so that this service would cease to exist someday, right? (LEOLINDA)

This category aims to analyze whether CSOs can overcome the barriers of assistentialism and become a space that promotes social change. In this regard, the teaching-learning activities within the institution and health promotion based on these activities will be discussed, aiming to understand CSO's role as a tool for social emancipation for that community.

The institution's assistentialist character was mentioned by the interviewees as a barrier to be overcome. According to the participants, CSO often does not promote any critical reflection or social change in that territory. The lack of community bonding leads to a situation where the community itself cannot understand the work that is and that should be performed in that space, which generates the maintenance of a type of work that does not focus on children and adolescents, nor on that community's emancipation.

There is not a clear objective, it seems that things are disconnected, you know? So, here comes a workshop facilitator of some kind, let's do it, then we do it... Then, there comes a teacher who wants to be a volunteer, he does it... So, I mean, it is more to occupy them rather than to think about a project, what it should be and what it should have. (LEOLINDA)

So this assistentialist thing is a little bit problematic because they actually say ah, let's think about the child, but the last thing they think about is the child. (NÍSIA)

It is noteworthy that, especially because it is a CSO, it is essential to overcome the barriers of assistentialism. Therefore, workers as well as children and adolescents should understand that this right is guaranteed by the Constitution, and not an act of charity or philanthropy. This conflict still exists, and stems from the old assistentialist practices of benevolence and compassion that have not been fully replaced by the understanding of social rights. This assistentialist culture is a major challenge to the effective implementation of social policies for children and adolescents (FONSECA, 2018). 
One of the obstacles to overcoming the barriers of assistentialism that was mentioned by the participants referred to the difficulties of public-private administration. This type of management affects the work of professionals, who often get "stuck" to bureaucracy for fear of losing State funding. One of the biggest obstacles of such administrative bureaucracy is the hiring of teachers, since, in Florianopolis, teachers are not regularly hired. In fact, they are temporarily employed and, every year, there is a new selection process. With the annual change of workers, it is impossible to establish ties with the children and the community, which leads to such assistentialist work, as every change requires time, bonding and trust, especially in a community

[...] It is especially because the teachers stay for only a year and, then, leave. So, there is no continuity to the work. So, all that institution's PPP mission ends up not being accomplished because there is no continuity to the work. It is constrained by fear of Social Welfare, the ghost of Welfare that will take away the institution's funds if we don't please the children and don't do all that they want and that their parents want. In short... it could be much more, but it isn't.... (MARTA)

[...] because when I evaluated myself at the end of the year, I was very disappointed with myself for not having thought about this before and for having thought about this only in the last few months, for not having proposed it, for not having seen it, you know? (LEOLINDA)

Similarly to the studied institution, in order to ensure their existence and prosperity, many other CSOs need to make a number changes in their action strategies to comply with the norms and ensure alliances with private companies, international institutions, and even the State. Thus, the daily routine of CSOs, in addition to undergoing adaptations, also needs to show the good results of their actions (MENDONÇA; MENEZES, 2017).

Even with these obstacles, the institution enables several health promotion actions such as the guarantee of adequate and healthy food (access to lunch, fruit, and snacks), and access to several workshops that are available, in addition to the physical education classes, which provide the expansion of the motor repertoire, body practices, and physical activities. The food provision at OSC is supervised by a nutritionist, who also evaluates the children through anthropometrics to identify cases of malnutrition and obesity. Many children do not have access to adequate amounts of food, so in addition to providing access to healthy food, CSO also becomes very important in ensuring food and nutritional security for these children and adolescents. 


\begin{abstract}
Wow, it plays a role that could be much greater, but even so it is transformative because of the experiences that are made possible for the children there. The workshops that they have contact with, that are offered there, allow them to expand their life repertoire, something that would not be possible without the NGO. [...] They had a wide range of experiences that they wouldn't have outside the NGO, although it is very limited, it allows them to have other experiences and give new meaning to their lives. (MARTA)
\end{abstract}

These actions are essential for improving these children's and adolescents' quality of life and for their protection. However, for emancipatory health promotion, they must be accompanied by critical and social reflection. Thus, in addition to the aforementioned initiatives, other initiatives that promote children's health were mentioned, such as health education projects and workshops, and even day-today CSO actions that address social, psychological, and cultural aspects. These actions also contribute to the protection and construction of autonomy, solidarity, collectivity, care, and the children's and adolescents' bonds. Acting from this perspective becomes crucial for those who seek health promotion focused on the production of subjects and social change (MOREIRA et al., 2009).

Although the institution itself enables protection for the children and adolescents, who, by staying at OSC after school hours, are not experiencing problems or other forms of violence in their homes, it is important for the institution to promote discussion and embracement to help them overcome such experiences. Thus, these issues are addressed at CSO through conversations and workshops with children and adolescents about: sex education; violence against children and adolescents; sexual abuse; non-violent communication; awareness about alcohol and other drugs; respect for diversity (ethnic, religious, sexual) and the different family structures. This year, the Brazilian regions and respect for cultural diversity were also addressed. Furthermore, as the study was conducted in an election year, conversations were held about how the electoral system works in Brazil. All these actions promote and create opportunities for coexistence, solidarity, respect for life, and the strengthening of bonds, seeking to build citizens who understand and respect human rights, democracy, and fundamental liberties, thus reducing violence and building solidarity and a culture of peace.

They really like competition, and I have realized that competitiveness is something that exacerbates violence and aggressiveness, and by gradually addressing the issue of cooperation, I thought it was time to work on cooperation along with competition, and competition in a healthy way. (MARTA) 


\begin{abstract}
Removing them from their vulnerable environment, bringing them here, and working on something. Showing them that there are other things. For example, the violence issue is something that we, it's routine, we always talk about it, [...] but for example, sometimes there are broader issues, like, I don't know, sexual violence. This year we sat down and talked about this, you know? Because they also need to understand what it is to be able to protect themselves from it. (NÍSIA)
\end{abstract}

Thus, despite these impasses and a strongly assistentialist character, it was observed, through the interviewees' statements, that the entity has the potential to create coping strategies to produce more relevant results for children and adolescents, seeking a critical understanding of the community's economic and social situation with the purpose of making CSO a space that no longer needs to exist. Some individual initiatives seeking to overcome these issues were reported, but unfortunately they depend on teachers' involvement and, probably, for this reason, they did not last.

[...] activities that involve the daily life, the reality, that involve the economic issue in this place, for example, where do people work here? They are always moving house because, I believe, the rent increases and they look for another house... And how is all this established? How are these things organized? So, activities more focused on daily life for them to think about. (LEOLINDA)

These initiatives refer to actions aimed at emancipating and training these children and adolescents for citizenship and democracy, instead of merely transferring knowledge and content. Therefore, emancipatory education becomes a very important teaching strategy in the quest to overcome the assistential character. According to Freire (2016), it is necessary to criticize and refuse the "banking model of education, which transfers knowledge to students through authoritarianism and follows a market logic that changes students into beings that are subjected to their educator. Education should be founded on practices based on horizontal relations, that consider the different scientific and popular knowledge, that understand the learner as the subject of knowledge and culture, and that work from the perspective of collectivity and democracy.

In this conception, education encompasses political and economic awareness, in the construction of subjects who fight for their rights. Thus, according to Freire (2016, p. 14), “[...] the educational vision cannot but be, at the same time, a criticism of the real oppression in which men live and an expression of their struggle to free themselves". From this perspective of learners as social, cultural, cognitive, ethical, 
and political subjects, it is possible to recover the sense of humanity that has been stolen from these people, making them subjects of their own education and life.

\section{Conclusion}

CSO has several health promotion initiatives for children and adolescents that promote their quality of life, ensure access to their social rights, and provide the development of democratic values and citizenship. The importance of the institution's actions in these children's and adolescents' lives is undeniable. However, the institution still maintains the assistentialist character because its actions do not aim at popular emancipation and social change in that community. There are some individual initiatives that are created by the workers themselves with the intention of developing critical and social knowledge. But these initiatives do not materialize because the professionals are not contractually employed and the institution does not implement these actions. Therefore, it is important that the CSO management and coordination itself create permanent strategies aiming at the community's emancipation.

Given the complexity of the demands met and the lack of intersectoral and transdisciplinary work, many of the problems remain unsolved, and the children, even when under the protection system, continue to suffer violence within the service itself. The institution as a place of protection for vulnerable children and adolescents should encourage health promotion actions that aim to provide comprehensive care and prioritize expanded networking, with horizontal dialogue and a focus on users.

Even with the inclusion of intersectorality in official CSO documents and in guiding public policies, it seems that its implementation is not effective in practice. Intersectorality still faces many obstacles, such as the lack of workers' knowledge, education that is alienated from the social problems faced by our society, the network's lack of preparation and articulation, and especially the participation of the civil society as a State partner, which generates even more difficulties due to its distance from the public network.

Another important obstacle to networking effectiveness lies in the constitution of our own society. Besides the change in professional training, the work in the intersectoral perspective will only be effective when public policies also take into account the users' demands. With a social structure based on neoliberalism and the minimal State, the goal is to ease social conflicts, not solve them in their essence, so 
segmented and fragmented programs and actions are implemented (BELLINI et al., 2013). Thus, a dialectical and contradictory relationship between intersectorality and public policies is revealed (CORRÊA, 2018).

$\mathrm{CSO}$ is a space that has been constituted by the organized civil society, a result of social movements, and that has a lot of potential to promote social change. The reflections about its performance pointed to the need for collective and permanent work that included the community, families and children. It would be important to include educational actions aiming at the reflection by these individuals and the community for a critical action on reality, since, in this way, health promotion can overcome the reductionism of the hegemonic understanding of health. In order to promote health it is necessary to act towards the community's emancipation and empowerment, aiming at reducing inequality and building a more equitable society. And if inequalities are the product of capitalist contradictions, it is necessary to educate critical citizens in order to overcome that system. ${ }^{1,2}$

\section{References}

BARBIANI, R. Violação de direitos de crianças e adolescentes no Brasil: interfaces com a política de saúde. Saúde em Debate, v. 40, p. 200-211, 2016.

BELLINI, M. I. B. et al. Políticas públicas e intersetorialidade em debate. I Seminário Internacional Sobre Políticas Públicas, Intersetorialidade e Família, Porto Alegre: EDIPUCRS, 2013.

BERLINGUER, G. Globalização e saúde global. Estudos avançados, v. 13, n. 35, p. 21-38, 1999. BRASIL. Ministério da Saúde. Secretaria de Vigilância à Saúde. Secretaria da Atenção à Saúde. Política Nacional de Promoção da Saúde. PNPS: revisão da Portaria MS/GM n. 687, de 30 de março de 2006. Brasília: 2015.

Ministério do Desenvolvimento Social e Combate à Fome. Secretaria Nacional de Assistência Social. Caderno de Orientaçóes: Serviço de Proteçáo e Atendimento Integral à Família e Serviço de Convivência e Fortalecimento de Vínculo. Brasília, 2010.

CARMO, M. E. do; GUIZARDI, F. L. O conceito de vulnerabilidade e seus sentidos para as políticas públicas de saúde e assistência social. Cadernos de Saúde Pública, v. 34, p. e00101417, 2018.

CORRÊA, M. C. et al. Entre limites e possibilidades: a intersetorialidade na rede de proteçấo da criança e do adolescente vítima de violência na cidade de Porto Alegre. Dissertação (Mestrado) - Programa de Pós-Graduação em Serviço Social, PUC-RS, Porto Alegre, 2018. 
FONSECA, L. R. et al. Politicas de atendimento a crianças e adolescentes no município de São Borja: um olhar para educação, saúde e assistência social. Dissertação (Mestrado em Políticas Públicas) - Programa de Pós-Graduação em Poliíicas Públicas da Universidade Federal do Pampa. São Borja-RS, 2018.

FREIRE, P. Pedagogia da autonomia: saberes necessários à prática docente. São Paulo: Paz e Terra, 2016.

GOHN, M. da G. Os sem-terra, ONGs e cidadania: a sociedade civil brasileira na era da globalização. São Paulo: Cortez, 2000.

JUNQUEIRA, Luciano A. Prates. A gestão intersetorial das políticas sociais e o terceiro setor. Saúde e Sociedade, v. 13, p. 25-36, 2004.

MENDES, J. M. R.; LEWGOY, A. M. B.; SILVEIRA, E. C. Saúde e interdisciplinaridade: mundo vasto mundo. Revista Ciência \& Saúde, v. 1, n. 1, p. 24-32, 2008.

MENDONÇA, E. S.; MENEZES, J. de A. Organizaçóes não-governamentais como dispositivos de poder: do bem-estar ao controle social. Fractal: Revista de Psicologia, v. 29, n. 3, p. 272-279, 2017. MINAYO, M. C. de S. O desafio do conhecimento: pesquisa qualitativa em saúde. São Paulo/Rio de Janeiro: Hucitec-Abrasco, 2010.

MONTAÑO, C. Pobreza, "questão social" e seu enfrentamento. Serviço Social \& Sociedade, v. 110, p. 207-287, 2012.

MOREIRA, J. et al. Educação popular em saúde: a educação libertadora mediando a promoção da saúde e o empoderamento. Revista Contrapontos, v. 7, n. 3, p. 507-521, 2009.

NAVARRO, V. Welfare e "keynesianismo militarista" na era Reagan. Lua Nova: Revista de Cultura e Politica, n. 24, p. 189-210, 1991.

PAIM, M. B. Açôes de promoção à saúde desenvolvidas pelo nutricionista ligado ao núcleo de apoio à saúde da família, na atenção primária no município de Florianópolis-SC. Trabalho de Conclusão de Curso. Universidade Federal de Santa Catarina, 2013.

POMBO, O. Interdisciplinaridade e integração dos saberes. Liinc em revista, v. 1, n. 1, 2005.

RIZZINI, I.; PILOTTI, F. J. (Eds.). A arte de governar crianças: a história das políticas sociais, da legislação e da assistência à infância no Brasil. São Paulo: Cortez, 2011.

VOGEL, A. Do Estado ao Estatuto. Propostas e vicissitudes da política de atendimento à infância e adolescência no Brasil contemporâneo. In RIZZINI, I.; PILOTTI, F. J. (Eds.). A arte de governar crianças: a história das políticas sociais, da legislação e da assistência à infância no Brasil. São Paulo: Cortez, 2011. p. 287-322.

WESTPHAL, M. F. Promoção da saúde e prevenção de doenças. In: CAMPOS, G. W. S. et al (Orgs.). Tratado de saúde coletiva. São Paulo: Hucitec; Rio de Janeiro: Ed. Fiocruz, 2009. 


\section{Notes}

${ }^{1}$ This study was conducted with support from the Coordination for the Improvement of Higher Education Personnel - Brazil (CAPES) - Funding Code 001.

${ }^{2}$ B. L. Selau: data collection and manuscript writing. D. F. Kovaleski: manuscript writing and revision. M. B. Paim: data collection and manuscript revision. 


\section{Resumo}

\section{Analisando a promoção à saúde de crianças} $e$ adolescentes em vulnerabilidade em uma organização da sociedade civil em Florianópolis-SC

Após a redemocratização, as parcerias entre o Estado e as organizações da sociedade civil são garantidas pela Constituição como ferramenta democrática. Com advento do neoliberalismo e a diminuição de investimento estatais em políticas sociais, essas organizaçóes se tornam protagonistas no cuidado com a saúde, a educação e a proteção de crianças em situação de vulnerabilidade. Este trabalho tem como objetivo analisar a promoção à saúde no atendimento de crianças e adolescentes em uma Organização da Sociedade Civil (OSC) de Florianópolis-SC. Trata-se de estudo de caso com abordagem qualitativa na qual foram realizadas entrevistas semiestruturadas, que foram transcritas e analisadas a partir do método de análise temática. A análise inferiu em duas categorias empíricas:

(1) Tecendo redes entre o Estado e a Sociedade Civil: a intersetorialidade na promoção à saúde; e (2) A OSC e os (des)caminhos em busca da promoção à saúde emancipatória. A análise apresentou que, apesar de a OSC incluir diversas iniciativas de promoção à saúde para crianças e adolescentes, ainda falta a efetivação do trabalho intersetorial; além disso, para uma promoção à saúde emancipatória, é necessário atuar em direção ao empoderamento da comunidade e da educação para reflexão crítica e social.

> Palavras-chave: crianças; adolescentes; promoção à saúde; intersetorialidade; organizações da sociedade civil. 